UDC 004.942:617.574-089.22

O.F. Dashchenko, DEng, Prof., Yu.M. Svinarov, $\mathrm{PhD}$, Assoc.Prof., O.M. Lymarenko, PhD, Assoc.Prof. Odessa National Polytechnic University, 1 Shevchenko Ave., 65044 Odessa, Ukraine; e-mail: aml28@mail.ru

\title{
COMPUTER MODELING AND NUMERICAL ANALYSIS OF THE PROSTHESIS TO FIX THE FOREARM FRACTURES
}

\begin{abstract}
О.Ф. Дащенко, Ю.М. Свінарьов О.М. Лимаренко. Комп'ютерне моделювання і чисельний аналіз ортопедичної конструкції для фіксації переломів кісток передпліччя. Переломи кісток передпліччя складають близько $15 \%$ випадків всіх переломів сегментів кінцівок. Найбільш часто зустрічається у спортсменів і людей, які потрапили в дорожньо-транспортну пригоду, та при бойових діях. Актуальність проектування і чисельного аналізу конструкцій для фіксації поламаних кісток визначається недостатньою досконалістю і дослідженнями ортопедичних стержневих апаратів фіксації. В роботі розв'язані важливі завдання сучасної травматології: наукове обгрунтування і розробка конструкції фіксатора; розробка методики визначення характеристик міцності і жорсткості конструкції фіксатора для лікування переломів кісток передпліччя. ANSYS.

Ключові слова: стержневі апарати фіксації, напружено-деформований стан, метод скінченних елементів,

O.F. Dashchenko, Yu.M. Svinarov, O.M. Lymarenko. Computer modeling and numerical analysis of the prosthesis to fix the forearm fractures. The forearm fractures constitute about $15 \%$ of all fractures of the limb segments. The most common they are among athletes and people involved in a traffic accidents or military actions. The relevance of design and numerical analysis of structures for fixing broken bones is determined with certain imperfections and insufficient research of orthopedic devices' fixation rod. The study is devoted to important problems of modern traumatology: scientific substantiation and development of fixing holder design; development of methods to determine the forearm fractures locking structure strength and rigidity characteristics for the treatment success.

Keywords: rod-based fixing device, stress-strain state, finite element method, ANSYS.
\end{abstract}

Introduction. Nowadays one of widely used methods for researching different designs in medicine and other fields of human activity is this one of computer simulation, based on the numerical methods (finite difference method, boundary elements method, finite elements method, etc.) $[1,2]$.

Implementation of some give numerical method depends on the task and applied software package. Numerical analysis allows calculating various object design modifications and various combinations of loads.

The chosen research topic relevance is due to the actual problems of forearm diaphysis bone (compact bone substance) fractures treatment and determined by insufficient perfection of both devices and corresponding treatment methods.

Literature review. From the reference sources it is known that the forearm fractures make $5 \ldots 15 \%$ of all extremities segments' fractures.

For the treatment of patients with limb segments injuries the most common device is the wire fixation structure designed by G.A. Ilizarov [3...6]. But use of this system involves a significant percentage of complications caused by a decrease in fixing wire stability and a cumbersome external design. This stipulated numerous scientists and researchers in the field of traumatology to seek for an alternative structure of compression and distraction apparatus (various external supports, units' connection, types of fixation).

The effected analysis shows that the most advantages among other trans-bone fixation devices are specific to rod-based fixation design. Several limitations as to their applicability relate to the osteo-

DOI 10.15276/opu.2.46.2015.23

(C) 2015 The Authors. This is an open access article under the CC BY license (http://creativecommons.org/licenses/by/4.0/).

КОМП’ЮТЕРНІ Й ІНФОРМАЦЙНІ МЕРЕЖІ І СИСТЕМИ. АВТОМАТИЗАЦІЯ ВИРОБНИЦТВА 
synthesis methods' problems, depending onto type and character of diaphysis bone (forearm in the given example) fractures.

While researching the relevant data, revealed is the shortage of data as to forearm fractures treatment external fixing devices' comparative calculations using the numeric methods.

The Aim of the Research embraces the scientific substantiation for the fracture fixing external prosthesis' construction with geometric dimensions' distortion determining methods elaboration.

Main Body. The considered structure study goal is to design a device for treatment of the forearm middle part fractures when long bones' diaphysis damage by developing alternative structures where displaced broken bone fragments' reposition is achieved by increasing the repositioning points' mobility levels. Such design is able to ensure the displaced bone fragments' correct position without plaster immobilization and, most importantly, maintaining the forearm's full mobility, and, due to compactness, without producing inconvenience to the patient.

The problem is solved with the auxiliary of the structure's external support in the form of a beam bearing the rods' receptacles with screw pins, fixing screwed rods, which are consistently passed through intact bone parts for their rigid fixation [7].

Using as the basis the adult forearm cross-sections scans, taken at Traumatology Department of the Odessa City Clinical Hospital No. 11 (equipment: Computerized Tomography Toshiba Asteion Super 4) the authors obtained data required for simulation. Then a 3D-model has been built that adequately reflects the forearm geometry. To determine the rigidity of forearm bone fragments' fixation with the transbone osteosynthesis device characteristic for several particular configurations and the range of possible functional loads, and to identify the optimal layout system and treatment strategy depending on the fracture type there was implemented fixation methods' computer modeling.

In mechanical engineering terms such systems represent spatial structures containing thickwalled circular and rectangular plates with holes, classic rods, flexible rods (wires) combined with different types of unions.

The mechanical engineering methods and mechanical researches often use simplified analytical calculation methods. The investigated object diagram is simplified for both the space system elements design (and their respective specific interconnections) and in terms of external loads representation.

The widespread use of modern computer technology in scientific research implies the need to revise the existing techniques. If previously the main focus has been centering onto calculation methods, using several simplifying assumptions and methods of artificial simplification, then the today's focal point relates to developing mathematical models the most effectively implemented with a PC. Here as efficient ones we do mean such models that require fairly simple software and less computer time, most completely reflecting the structure's actual geometry and behavior.

The most convenient for solving mechanical problems in medical research as well as in other fields of science and technology became the linear spaces' discrete theory methods: matrix calculus, potential method, boundary elements method and finite elements method (FEM).

For problem solving, the entire structure must be represented, FEM using, as a finite set of elements: rods, triangular and rectangular plates, tetraedrs and parallelepipeds interconnected at nodal points.

The starting point in the finite-element analysis of any structures, including orthopedic devices, is building a geometric model and a finite-element models.

The geometric model reflects the structure's shape and size and the finite-element model contains complete information about the nodal points and finite elements position as well as the interactions between individual nodes and elements.

Theoretically there exists a possibility of finite-element analysis without the use of geometric models, but in this case, required is to set all nodes' coordinates manually and build finite element models, that being practically impossible for complex designs. When using a geometric model that disadvantage is eliminated, since the current finite-element analysis programs allow to get automatically the finite-element structure of the calculated design which is based on its geometrical model. Hence, this approach in modeling orthopedic systems is more preferred. 
The fractures treatment devices' rod system elements can be simulated using the following types of finite elements:

- Beam and rod;

- Plate;

- Volumetric.

The geometric model should match the type of element used at the partition by finite elements. If the structure discretization samples the design into beam and rod elements, the geometric model should consist of lines; when plate type elements that should be surfaces and as to volumetric elements these will be elementary volumetric bodies.

The authors consider models consisting of rod-type and three-dimensional finite elements because they provide matching geometry between the models and real structures (Fig. 1).

Results. Both models' approximation uses rod-type finite element BEAM188 of ANSYS program elements library. The element is intended for space problems resolving. The element properties are set by describing the characteristics of cross-section, material properties (elastic modulus and Poisson's ratio) and the elastic base.

This finite element has two nodal points with six degrees of freedom at each: motion directed to the nodal coordinates' system axes $X, Y, Z$ and angles of rotation respectively to these axes $\varphi_{x}, \varphi_{y}, \varphi_{z}$.
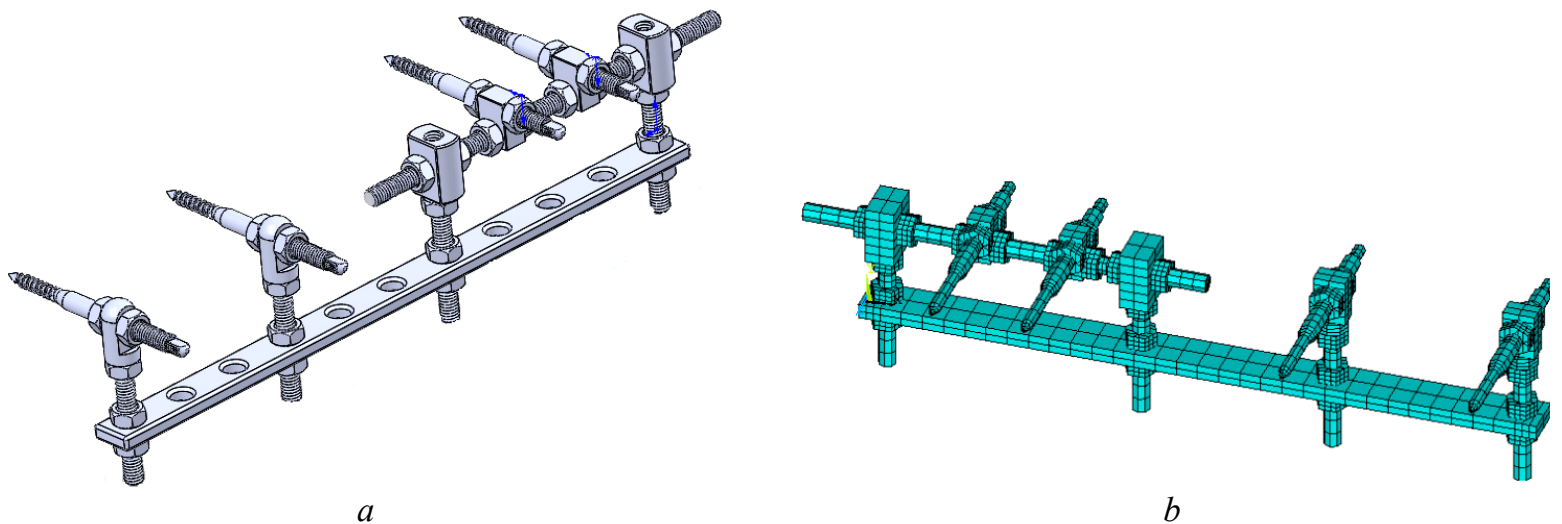

Fig. 1. Computer simulation using volumetric FE (a) and rod-type FE (b)

To display the geometric characteristics the original structural elements and clamps crosssections were designed using special feature of the ANSYS - Taper Section (37 cross-sections built and recorded into database).

The model splitting into volumetric finite-elements is performed using the Solid45. That element is classified as follows: volumetric (3D) element used for solving problems in the deformable solids' mechanics; it is defined by eight nodal points, each having three degrees of freedom: linear displacement in the direction of nodal coordinate system's axes $X, Y, Z$.

In both cases, the fixation conditions should be selected so that they prevent structure from motion, but do not involve any deformation.

Geometrical and mechanical characteristics of the devices are determined by the known deformable solids' mechanics dependences, the experimental data and reference sources

The bone elasticity modulus is admitted equal to $E_{b}=2 \cdot 10^{4} \mathrm{MPa}$ steel elasticity modulus $E_{s t}=2,1 \cdot 10^{5} \mathrm{MPa}$, titanium elasticity modulus $E_{t}=1,2 \cdot 10^{5} \mathrm{MPa}$ (Fig. 2).

As a result of that calculation for each variance the stress-strain state parameters necessary for analysis are found:

- $\sigma_{e q}$ - equivalent stress according to the Huber-Mises hypothesis;

- USUM - equivalent displacements. 


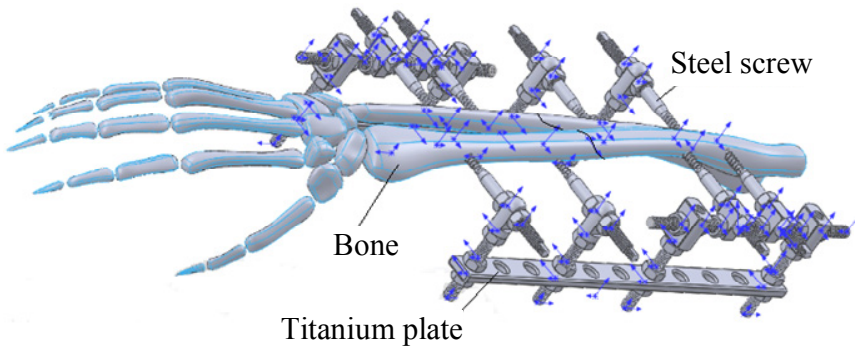

Fig. 2. Computational model of the studied objects

Maximum values of the given stress-strain state parameters for all calculated versions are summarized in the table.

Maximum values of the stress-strain state parameters

\begin{tabular}{l|c|c}
\hline $\begin{array}{c}\text { Stress-strain state } \\
\text { parameters }\end{array}$ & Fixing component (rod-based model) & Fixing component (volumetric model) \\
\hline$U S U M$ elbow area, $\mathrm{mm}$ & 0,0027 & 0,0019 \\
\hline$U S U M$ fracture area, $\mathrm{mm}$ & 0,0108 & 0,01 \\
\hline$U S U M$ writ area, $\mathrm{mm}$ & 0,0267 & 0,0243 \\
\hline max $\sigma_{e q}, \mathrm{MPa}$ & 17,988 & 23,616 \\
\hline
\end{tabular}

Conclusions. The numerical experiment results led to some conclusions. Rod-based system respective deformation:

- Model of the rod-type finite elements

$$
\varepsilon_{r}=\frac{\Delta l}{l}=\frac{0,0267}{235}=1,136 \cdot 10^{-4} ;
$$

— Model of the volumetric finite elements

$$
\varepsilon_{v}=1,034 \cdot 10^{-4} \text {. }
$$

Comparing the numerical values of stresses and displacements obtained by finite-elements analysis of the studied rod elements' structures with respective values obtained at calculation using volumetric elements we come to conclude about reliability of assumptions adopted at the stages of geometrical and finite-elements modeling. This conclusion is also correct for the boundary conditions, as well as for values and nature of external loads applied.

The obtained results can serve as a basis for developing new structures purposed for the forearm diaphyseal fractures treatment.

\section{Література}

1. Калініченко, П.М. Напружений стан товстостінного циліндра 3 концентраторами / П.М. Калініченко, О.М. Лимаренко, Ю.В. Зяблов // Тр. Одес. политехн. ун.-та. — 2006. Вып. 2(26). - С. $20-23$.

2. Оробей, В.Ф. Применение численных методов к расчету элементов судовых конструкций / В.Ф. Оробей, А.О. Немчук, А.М. Лимаренко // Вісн. Одес. нац. ун-ту. — 2009. — № 26. — С. $85-90$.

3. Kiran, M. Ilizarov's method for treatment of nonunion of diaphyseal fractures of the humerus / M. Kiran, R. Jee // Indian Journal of Orthopaedics. — 2010. — Vol. 44, No. 4. — PP. 444 - 447.

4. The stiffness characteristics of hybrid Ilizarov fixators / O. Baran, H. Havitcioglu, H. Tatari, B. Cecen // Journal of Biomechanics. — 2008. — Vol. 41, Issue 14. — PP. 2960 - 2963.

5. Khanfour, A.A. Versatility of Ilizarov technique in difficult cases of ankle arthrodesis and review of literature / A.A. Khanfour // Foot and Ankle Surgery. — 2013. — Vol. 19, Issue 1. — PP. 42 — 47. 
6. Bor, N. Ilizarov method for gradual deformity correction / N. Bor, G. Rubin, N. Rozen // Operative Techniques in Orthopaedics. - 2011. - Vol. 21, Issue 2. - PP. $104-112$.

7. Пат. 87293 Україна, МПК А61В 17/58. Пристрій для черезкісткового остеосинтезу діафізарних переломів кісток передпліччя / Бодня O.I., Баккар Тарек; заявник та патентовласник Одеський національний медичний університет. — № а201300787; заявл. 23.01.2013; надр. 10.02.2014, Бюл. № 3.

\section{References}

1. Kalinichenko, P.M., Limarenko, A.M. and Zyablov, Yu.V. (2006). The stressed state of a thick-wall cylinder with concentrators. Odessa Polytechnic University: Researches, 2, 20-23.

2. Orobey, V.F., Nemchuk, A.O. and Limarenko, A.M. (2009). Application of numerical methods for calculation of elements of ship structures. Herald of Odessa National Maritime University, 26, 85-90.

3. Kiran, M. and Jee, R. (2010). Ilizarov's method for treatment of nonunion of diaphyseal fractures of the humerus. Indian Journal of Orthopaedics, 44(4), 444-447.

4. Baran, O., Havitcioglu, H., Tatari, H. and Cecen, B. (2008). The stiffness characteristics of hybrid Ilizarov fixators. Journal of Biomechanics, 41(14), 2960-2963.

5. Khanfour, A.A. (2013). Versatility of Ilizarov technique in difficult cases of ankle arthrodesis and review of literature. Foot and Ankle Surgery, 19(1), 42-47.

6. Bor, N., Rubin, G. and Rozen, N. (2011). Ilizarov method for gradual deformity correction. Operative Techniques in Orthopaedics, 21(2), 104-112.

7. Odesa National Medical University. (2014). Device for transosseous osteosynthesis of diaphyseal fractures of forearm bones. Ukraine Patent: UA 87293. 